\title{
Participating in the Memorials for Helmut Kallmann (1922-2012)
}

\author{
BY ELAINE KEILLOR
}

Based on the author's remarks and participation at the Memorials for Helmut Kallmann held in Ottawa on 14 February 2012 and in Toronto on 10 April 2012.

Helmut Kallmann's book, A History of Music in Canada, 1534-1914 (1960), made its appearance in our home soon after its publication. I can recall that my mother was so thrilled to find the section on her former teacher, W.O. Forsyth.

My first personal contact with Helmut happened a few years later. By that time I was a graduate student at the University of Toronto and had decided to do a major research paper on W.O. Forsyth. While I was rummaging through my mother's papers to find information, I came across several clippings that she had snipped from the Toronto Globe in the mid-1930s. These were write-ups, each on a different Canadian composer with a listing of compositions.

Helmut Kallmann had taken up his new position as head of the Music Division at the National Library of Canada (now known as Library and Archives Canada) in 1970. I decided to write him to find out if he knew about these particular articles.

Imagine my delight when shortly after I received a long hand-written note from Helmut, thanking me profusely for bringing this information to his attention. He reported that he and his staff had been able to track down the whole series and as a consequence obtained much information that had not previously been known to him. Soon I was involved, along with other graduate students across the country, in writing entries for his new big project, the Encyclopedia of Music in Canada.

In 1977 I arrived in Ottawa to take up my new position at Carleton University. My duties included teaching Canadian music courses at both the undergraduate and graduate levels. At that point Helmut's book was no longer in print, so I had to find ways of exploring Canadian music topics without any textbook. I was soon making regular trips to the National Library, and Helmut would give me wonderful ideas about what to have students do to procure more information on Canadian music.

In 1982 a group of us involved with teaching and researching Canadian music met to discuss the lack of availability of pre-1950 written compositions. To fill that lacuna we formed the Canadian Musical Heritage Society. Over the next two decades, Helmut was the centre of that organization as we tracked down and sifted through compositions in all genres. The resulting 25 volumes published by the Society included only some 1500 works of the approximately 35,000 that we managed to discover. At our meetings, usually held at Carleton University, Helmut would gently give us direction and advice. 
His editing skills were legendary, for the essays and notes that accompanied each volume in the series and for the music scores.

His mentorship to me and his contributions as a committee member on theses of my graduate students are just some of the wonderful memories I have, when I look back at the privilege of working with such a knowledgeable but modest individual. The last written message that I received from Helmut is one that I will always treasure. It expressed his pleasure at reading once again what he called my "fine book," Music in Canada, which had come out in paperback (2008). Of course, I would not have been able to even attempt to write such a book without his previous research, particularly for the Encyclopedia, along with the wonderful musical resources he had accumulated at the National Library.

To honour his memory at the Memorial in Ottawa, I chose to play two Canadian piano pieces. The first was a movement from the Suite for Piano, written by Leo Smith, probably in the 1930s. Smith was one of Helmut's professors when he was a student at the University of Toronto. In 1981, the centenary of Leo Smith's birth, Helmut organized a special exhibition of Smith materials. Then he decided that there should be a concert of works by Leo Smith. I was one of the musicians involved in performing several works: some of Smith's songs with soprano Gloria Jean Nagy, chamber music for cello and piano with cellist Joan Colquhoun, and the Suite for Piano. The CBC recorded the recital on 26 November 1981 for later broadcast. For the Memorial in Ottawa, I chose to play the slow second movement of the Suite.

After Kallmann's retirement from the National Library, John Beckwith and Fred Hall put together a book in his honour, entitled Musical Canada (1988). It included four new compositions, three for piano and one for voice. As my second selection at the Ottawa Memorial, I performed the piano composition by Cliff Ford, who was the executive director of the Canadian Musical Heritage Society at the time. Cliff decided to write a Fantasy based on the ballad, "Summer and Winter," by J. P. Clarke, a composer in whom Helmut had taken a particular interest. Clarke (1808-1877) was the first person to receive a Bachelor of Music degree from a Canadian university. He is also the first Canadian composer for whom a number of scores in various genres have survived. I suspect that Helmut also favoured Clarke because by 1847 , he was conducting complete symphonies of Mozart and Beethoven in Toronto.

In any case, I think Cliff tries to also give a musical picture of how Helmut carried out his investigations on Canadian music. The opening shows him trying various paths to find more compositions. Later on, there seem to be "eureka" moments when he has found a new publication or manuscript. Helmut sits down at his piano and plays a bit of the newly found work, and then he is off searching for another.

At the Memorial for Helmut Kallmann held in Toronto, I had the honour of performing another piano composition written especially for the Beckwith/Hall book. John Weinzweig had known Helmut since the 1940s, and particularly wished to honour him for his tireless work in documenting, collecting, and promoting the music of Canadian 
composers past and present. Weinzweig told me that his piece used idioms from jazz, specifically the percussive and rhythmic character of stride piano that had developed in the 1920s and '30s. He said that he could use the word "Stride" in the title, but wanted to add something that would more clearly connect it with the work accomplished by Kallmann. I suggested the siglum CanOn, used for the National Library of Canada in the volumes of the Canadian Musical Heritage Society. As a result, the piece is entitled CanOn Stride. In my opinion this piece gives us a sense of Kallmann, actively involved in the musical developments of North America, and particularly of Canada, his adopted country.

Dr. ElaINE KeILlOR, Distinguished Research Professor Emerita Carleton University, has supervised the creation of four websites dealing with First Peoples' culture and music, including Native Drums, Native Dance, Path of the Elders, and First Encounters. In May 2012, Gala Records released her four-CD recording, Sounds of North: Two Centuries of Canadian Piano Music, dedicated to the memory of Helmut Kallmann. 